\title{
Handling construction waste of building demolition
}

\author{
Terezie Vondráčková ${ }^{1, *}$, Luboš Podolka ${ }^{1}$, and Věra Voštová ${ }^{2}$ \\ ${ }^{1}$ Institute of Technology and Business in České Budějovice, Department of Civil Engineering, 37001 \\ České Budějovice, Czech Republic \\ ${ }^{2}$ Czech Technical University in Prague, Faculty of Transportation Sciences, Horská 3, 12803 Prague, \\ Czech Republic
}

\begin{abstract}
Some building defects lead to their demolition. What about construction and demolition waste? According to the Waste Act 185/2001 Coll. and its amendment 223/2015 Coll., which comes into force on January 1,2017 , the production of waste has to be reduced because, as already stated in the amendment to Act No. 229/2014 Coll., the ban on landfilling of waste will apply from 2024 onwards. The main goals of waste management can thus be considered: Preventing or minimizing waste; Waste handling to be used as a secondary raw material - recycling, composting, combustion and the remaining waste to be dumped. Company AZS 98 s. r. o. was established, among other activities, also for the purpose of recycling construction and demolition waste. It operates 12 recycling centers throughout the Czech Republic and therefore we have selected it for a demonstration of the handling of construction and demolition waste in addressing the defects of the buildings.
\end{abstract}

\section{Introduction}

The contemporary construction is trying to reflect the requirements of sustainable development. The basic principles of sustainable development include efficient use of energy, water and other resources, the protection of indoor climate of buildings and human health, reduce waste and pollution [1]. Construction and demolition waste is a result of various construction activities, construction, maintenance and reconstruction of buildings, various construction modifications of completed constructions and removal of buildings. Over half of the total production of all waste in the Czech Republic consists of construction and demolition waste. Construction and demolition waste arises:

- when setting up buildings (buildings),

- their maintenance,

- when changing buildings (buildings),

- removal of buildings (buildings).

This waste is currently almost completely used because construction and demolition waste is a significant source of secondary raw materials. The Waste Management Plan of the Czech Republic for the period 2015-2024 sets a target for construction and demolition

\footnotetext{
${ }^{*}$ Corresponding author: 13260@mail.vstecb.cz
} 
waste and prepare at least $70 \%$ of this waste for re-use. This objective is based on Directive 2008/98 / EC of the European Parliament and of the Council on waste.

Under the term construction and demolition waste (CDW) we can imagine what remains after the modification, repair or demolition of a building. They are bricks, masonry, tiling, wooden structural elements, and anything else that remains after that or that construction. Construction waste and demolition waste are also considered to be remnants of various wiring. So electrical wiring, water and waste piping. Or the excavation rock. All of these materials are recyclable. However, separation is required for their successful recycling (or further processing). First of all, the separation of contaminated components and then the material separation. It should also be noted that such waste can be polluted by materials that legislation perceives as hazardous waste. Then they must be treated as hazardous waste or detoxified for recycling [2].

According to the Waste Catalogue, construction and demolition wastes are included in group 17 and their basic subgroups are listed in Tab. 1.

Table 1. Basic CDW Subgroups, according to the Waste Catalogue of Annex 1 [3].

\begin{tabular}{|c|c|}
\hline $\begin{array}{l}\text { Catalogue name of the } \\
\text { waste subgroup }\end{array}$ & Waste \\
\hline 1701 & Concrete, bricks, ceramic products and bags \\
\hline 1702 & Wood, glass and plastics \\
\hline 1703 & Bituminous mixtures, tar and tar products \\
\hline 1704 & Metal (including their alloys) \\
\hline 1705 & $\begin{array}{l}\text { Soil (including excavated soil from contaminated sites), stones and } \\
\text { extracted debris }\end{array}$ \\
\hline 1706 & Insulating materials and building materials containing asbestos \\
\hline 1707 & - \\
\hline 1708 & Plasterboard construction materiál \\
\hline 1709 & Other construction and demolition waste \\
\hline
\end{tabular}

The whole CDW process has its origins in the mining of building materials, which we take as primary building materials. After mining, these raw materials and materials are processed on the product, followed by the use of a statement in land or road construction, followed by demolition and ending with landfill removal, whether CDW is used for landscaping or reclamation. An integral component is also the waste generated during earthworks - the excavated soil, which occupies the largest proportion of the volume of construction waste.

A simple breakdown of construction waste is divided into four groups - Figure 1, based on the average percentage of the main CDW components:

- $(65-75 \%)$ Soil from excavations and debris.

- $(5-20 \%)$ Demolition building rubble.

- (10 - 15\%) Asphalt mixtures, bitumen.

- $(5-15 \%)$ Waste from construction sites

The share of individual fractions of construction waste is highly variable within the Czech Republic. The reason is different urbanization, industrialization, different construction technologies, density of built-up area and number of demolitions in individual regions.

The production of construction waste in 2008-2015 can be seen in Table 2. Data in the table come from the CENIA - ISOH database. Table 2 lists the groups of construction wastes that are most often produced and therefore their volume is higher than other groups and the groups of the most commonly used construction waste for subsequent recycling and production of recyclates. It can be seen from Table 2 that the production of construction 
and demolition waste is rather constant. An exception to the amount of production is formed by group 1705 - soil, debris and stones, which has been declining in recent years.

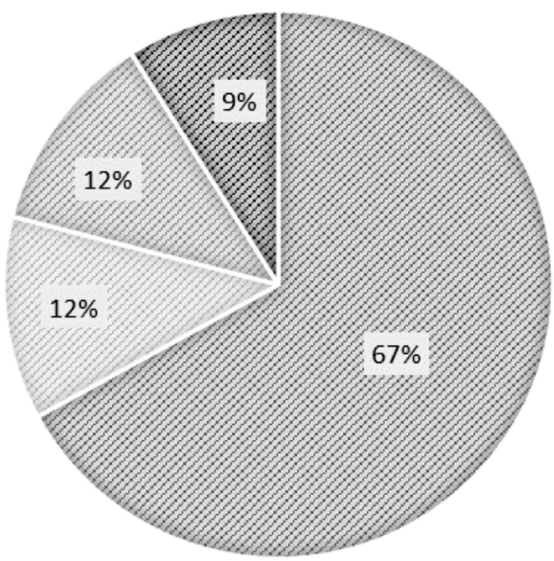

\author{
BASIC GROUP \\ - Soil from excavations and debris \\ - Demolition building rubble \\ Asphalt mictures, bitumen \\ Waste from construction site
}

Fig. 1. Segmentation of basic CDW groups.

Table 2. CDW production in the Czech Republic [4].

\begin{tabular}{|c|c|c|c|c|c|c|c|c|c|c|c|}
\hline \multirow{2}{*}{ Cat. n. } & Waste & \multicolumn{7}{|c|}{ Year } \\
\cline { 3 - 10 } & $\mathbf{2 0 0 8}$ & $\mathbf{2 0 0 9}$ & $\mathbf{2 0 1 0}$ & $\mathbf{2 0 1 1}$ & $\mathbf{2 0 1 2}$ & $\mathbf{2 0 1 3}$ & $\mathbf{2 0 1 4}$ & $\mathbf{2 0 1 5}$ \\
\cline { 3 - 10 } 1701 & $\begin{array}{c}\text { Concrete, bricks, tiles and } \\
\text { ceramics }\end{array}$ & 2934 & 2998 & 3167 & 3033 & 3444 & 3545 & 3625 & 3962 \\
\hline 1703 & $\begin{array}{c}\text { Bituminous mixtures, tar and } \\
\text { tar pitch }\end{array}$ & 445 & 516 & 466 & 443 & 531 & 560 & 584 & 575 \\
\hline 1705 & $\begin{array}{c}\text { Soil (including excavated soil } \\
\text { from contaminated sites), } \\
\text { stones and extracted debris }\end{array}$ & 11396 & 10708 & 10845 & 9053 & 8908 & 10094 & 11632 & 16726 \\
\hline 1708 & $\begin{array}{c}\text { Construction material on the } \\
\text { base of gypsum }\end{array}$ & 6 & 7 & 7 & 8 & 7 & 7 & 9 & 8 \\
\hline 1709 & $\begin{array}{c}\text { Other construction and } \\
\text { demolition waste }\end{array}$ & 497 & 580 & 614 & 630 & 496 & 502 & 530 & 620 \\
\hline & Total & 15278 & 14809 & 15099 & 13167 & 13386 & 14808 & 1380 & 21891 \\
\hline
\end{tabular}

\title{
2 Recycling of construction and demolition waste
}

As can be seen, under construction waste we can imagine what remains after the demolition of a building. They are bricks, masonry, tiling, wooden structural elements and anything else that remains after one or the other building, road, or the like. Construction waste also includes remnants of various types of building wiring. So electric wiring, water and waste piping. Or the excavation rock. Although it may sound odd, these materials are recyclable. However, separation is required for their successful recycling (or further processing). Above all, the separation of contaminated components and then separation by material. Excavating soil, for obvious reasons, is not necessary to separate. Account should also be taken of possible contamination of materials that the legislation then treats as hazardous waste.

Recycling of construction and demolition waste is largely understood as a "simple" treatment during which its physical properties change. Building wastes are a valuable source of materials that can reduce the need for extraction or production of new raw 
materials and materials. Based on experience from Europe, it can be said that the recycling boundary (or other recovery of construction and demolition waste) may be close to $90 \%$. With recycling systems, building waste can return to the construction industry as a fullfeatured material.

The recycling of construction waste began in Czech Rep. since the 1990s. The most common way of recycling CDW is crushing. Subsequently, everything is sorted to make the fractions easy to use for further construction, replacing raw materials from natural sources. The main benefit of recycling of construction and demolition waste is the reduction of the need to extract raw materials and reduce the cost of new building materials. This can limit the opening of new quarries or sandbanks. In addition, the building recyclates, which are replaced for instance natural aggregates, can be purchased at the fractional price of the extracted natural stone.

The concept of CDW recycling technology can be called the complete process of converting unsorted, mixed or different construction waste into sorted recyclates of differently selected fractions of $4 \mathrm{~mm}$ to $125 \mathrm{~mm}$. The procedure is such that materials that can be re-offered for sale are first separated by hand. These are mainly brick elements, roof tiles. Other materials are also separated - glass, metals, paper, plastics, wood (with fuel and building resolution) and finally unusable waste accumulated in the appropriate containers, which is taken to a municipal waste landfill. The next step is shredding and sorting.

\subsection{Technology of recycling}

There are two ways of recycling technology:

Recycling process carried out directly on the site where the CDW is being built - A CDW storage facility is provided at the construction site, its processing and use is directly conditional on the site. The benefits of using this recycling method are to minimize costs and charge for CDW removal and landfill. An important advantage is the use of recycled material for further construction. The disadvantages of using this recycling option include obtaining the necessary recycling permit at the site of construction and providing for the recycling process, ie, the place where the recycling will take place and the need to use the recycled product $[5,6]$.

The recycling process carried out at the place of the permanent establishment. Establishment provide the complex CDW disposal. This activity involves the reception of waste, its processing and, as a result, its sale. The removal and sorting of SDOs into recycling plants is only possible in accordance with the rules of the relevant facility. The benefits of using this recycling process are: minimum space requirements, recycling of CDW types and continuous waste disposal. Among the disadvantages are financial factors such as landfill and transport.

\section{Recycling technology at AGS 98, I.I.c.}

AZS 98's first recycling center was established in 2004 in Pilsen, Borská pole. The company has built and operated recycling centers in some districts at its own expense. To date, a total of 14 recycling centers have been operated. In some centers, besides recycling of construction waste, they also deal with the crushing of natural stone (Barbora Jáchymov), reclamation of the area after mining (Uhliřrské Janovice). The company operates recycling in both ways, ie at both the waste site and recycling centers.

Thanks to the quality of services and other activities, the company has been certified by Czech Building Standart (CBS) EN ISO 9001: 2001, CBS EN ISO 14001: 2005, CBS OHSAS 18001: 2008 and is a member of the Association for the Development of Building Materials Recycling. 
Mobile recycling technology at AZS 98 1.1.c is carried out by bringing a recycling line containing a mobile crusher, screener, loader and possibly an excavator to the collection site of the building waste. The next step is the crushing and sorting according to the required fraction, and then recyclate is used at the construction site. The quality of the resulting recycled material also results from the processes before direct crushing. The maximum quality of the recyclate is ensured by a magnetic separator and a lining strip and a calibrated weight for accurate pricing. Mobile recycling is only possible if the volume of construction materials exceeds 500 tons.

The recycling of CDW at the building waste recycling center takes place similarly, with the difference that construction waste is imported by both the company itself and other suppliers. The reception of construction waste is in accordance with the valid operating rules, which are approved by the relevant Regional Authority. The CDW is then accepted at the recycling center and classified according to the Waste Catalog. Crushing and sorting according to the fractions takes place after the accumulation of quantities economically beneficial for recycling. Whether recyclates are suitable for further use is verified by regular testing by an accredited testing center. It assesses not only the environmental impact, but also technological analyzes in terms of their use. All of these processes take place at fourteen recycling centers of AZS 98 1.1.c., located in four regions of the Czech Republic.

\subsection{Material flow}

The material flow is considered to be CDW's movement from its production, utilization or further disposal. Material flows at AZS 98 are listed in Table 3 [7].

Table 3 compares the volume of intake of construction and demolition waste with expenditure of the recyclate. This is the entire CDW income that was processed and issued by AZS 98 1.l.c. The difference in values may indicate either a larger quantity of the material being issued or, on the contrary, a larger quantity of material received. If the delivery value is greater than the acceptance value, it means that the demand for recycled material in the monitored center was higher and therefore the material was taken out of stock or out of stock from the previous year. This process is similar in most recycling centers. Graphic processing of Table 3 is in Figure 2.

Table 3. Material Flows Survey for 2014 at AZS 98 1.1.c.

\begin{tabular}{|c|c|c|c|c|c|}
\hline \multicolumn{7}{|c|}{ Amount of CDW receipt and issue of recyclate in 2014 } \\
\hline Center & District (NUTS4) & Region (NUTS3) & Receipt [t] & Issue [t] & Difference [t] \\
\hline Valcha & Plzeň & Plzeňský & 74585.49 & 76200.43 & 1614.94 \\
\hline Jáchymov & Karlovy Vary & Karlovarský & 0.00 & 2077.74 & 2077.74 \\
\hline Stř́bro & Tachov & Plzeňský & 6583.11 & 5907.30 & 675.81 \\
\hline Blovice & Plzeň - jih & Plzeňský & 2446.59 & 2872.44 & 425.85 \\
\hline Podbořany & Louny & Ústecký & 5621.65 & 3988.10 & 1633.55 \\
\hline Sadov & Karlovy Vary & Karlovarský & 11315.12 & 12741.49 & 1426.37 \\
\hline Tachov & Tachov & Plzeňský & 2103.21 & 4589.99 & 2486.78 \\
\hline Újezd & Domažlice & Plzeňský & 2623.55 & 445.73 & 2177.82 \\
\hline Cheb & Cheb & Karlovarský & 8043.86 & 664.00 & 7379.86 \\
\hline Ostř̌edek & Benešov & Středočeský & 4623.22 & 1291.50 & 3331.72 \\
\hline Rokycany & Rokycany & Plzeňský & 21612.17 & 14941.93 & 6670.24 \\
\hline Zavlekov & Klatovy & Plzeňský & 8064.34 & 6655.94 & 1408.40 \\
\hline Chmeliště & Kutná Hora & Středočeský & 1228.32 & 0.00 & 1228.32 \\
\hline Libočany & Louny & Ústecký & 3200.00 & 25,00 & 3175.00 \\
\hline \multicolumn{7}{|c|}{ Total in tonnes } & $\mathbf{1 5 2} \mathbf{0 5 0 . 6 3}$ & $\mathbf{1 3 2} \mathbf{4 0 1 . 5 9}$ & $\mathbf{1 9 6 4 9 . 0 4}$ \\
\hline
\end{tabular}


Although the direct waste recycling process does not run evenly every day, AZS 98's concept is to use recycling centers as "bottomless landfills". The principle is to recycle the received SDO volume at the recycling center and sell the same volume of CDW already recycled. Which, according to the volumes, meets this company.

It is also important to mention the use of recycled material by the company itself, not only for backfills and the like, but also for the production of brick concrete, from which the concrete cubes for dry reinforcement are also produced. The company is still trying to improve the quality of the recyclate and its further use, therefore it has long been cooperating with CTU in Prague, the Faculty of Civil Engineering. There are several projects underway to research possible recycling of recycled material.

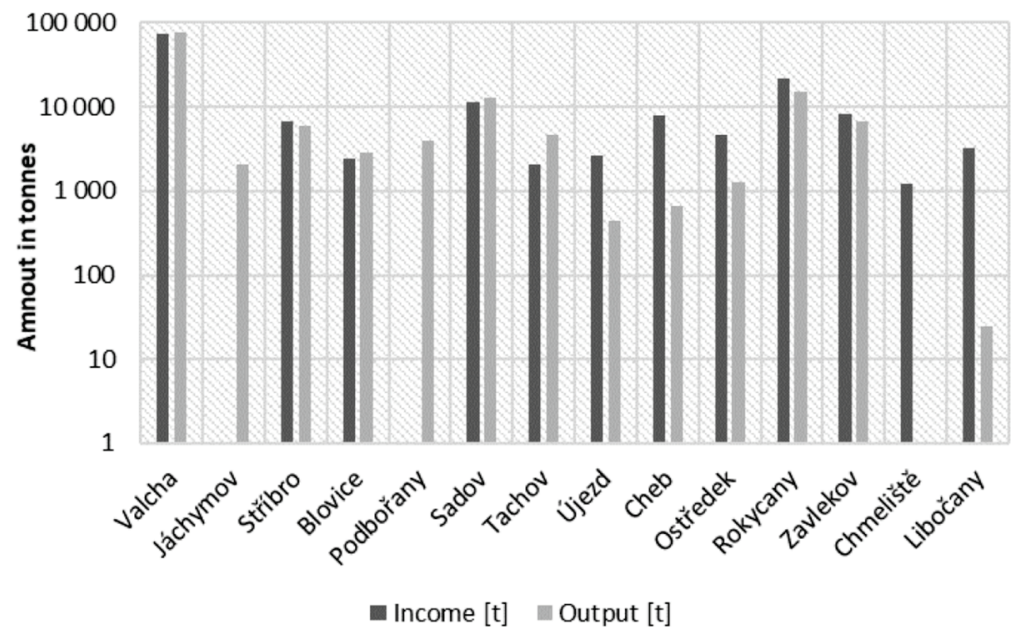

Fig. 2. Comparison of Material Income and Output at AZS 98 1.l.c.

\section{Conclusion}

Company AZS 98 1.l.c. Successfully solves the situation with the handling of construction and demolition wastes, as evidenced by the high weight of CDW used [8]. The system of disposal of construction and demolition waste in this company may be an example of good recycling and general waste management for other companies. The contribution came from the preparation of the grant plan.

\section{References}

1. M. Kraus, D. Kubečková, AMR 1041, 3-6 (2014)

2. M. Škopán, Systems for the recycling of construction and demolition waste. Available on http://stavebni-technika.cz/clanky/systemy-recyklace-stavebnich-a-demolicnichodpadu

3. CENIA. Available on http://isoh.cenia.cz/groupisoh/

4. Czech Statistical Office. Available on $h$ ttps://vdb.czso.cz/vdbvo/uvod.jsp

5. V. Voštová, V. Vlastimil, Logistics of waste management (CTU, 2009).

6. S. Szabo, Journal of Applied Economic Sciences 10, 1153-1159 (2015)

7. The official website of the company AZS 98 s.r.o. Available on http://www.azs98.cz/

8. T. Vondráčková, V. Voštová, V. Nývlt, Matec Web of Conferences 93, 03005 (2017) 